\title{
THE CHALLENGES IN ENFORCING POST DIVORCE ORDERS OF NATIVE COURTS IN EAST MALAYSIA
}

\author{
Hanna Ambaras Khan* \\ Nora Abdul Hak ${ }^{* *}$ \\ Najibah Mohd Zin ${ }^{* * *}$ \\ Roslina Che Soh ${ }^{* * * *}$
}

\begin{abstract}
The native court in Malaysia comprises of Mahkamah Anak Negeri Sabah and Mahkamah Bumiputera Sarawak. The existence of this court is recognised by the Malaysian Government and they are mentioned in the Federal Constitution of Malaysia. Although these courts are given power and authority in dealing with the personal law of natives in each state, there are challenges in enforcing post-divorce orders made by these courts. This article is significant since there is a dearth of study on this topic. The main objective of this article is to examine the enforcement of post-divorce orders of native courts within East Malaysia. It will also explore the problems and challenges of divorcees in enforcing divorce orders and provide recommendations to improve the existing system. This article adopts library-based and qualitative research method which consists of group discussions and interviews with the village headman (ketua kampung), headman (penghulu), community leader, native courts' judges, native court of appeal's judge, registrar of native court and several divorcees. The result of this research identified four challenges vis-a-vis: the capability to find the husband upon the issuance of the divorce order; second, husband's default payment of maintenance; lack of manpower in enforcing the order and lastly, husband's
\end{abstract}

* Senior Lecturer, School of Business and Economics, University Putra Malaysia.

** Professor, Department of Legal Practice, Ahmad Ibrahim Kulliyyah of Laws, International Islamic University of Malaysia. Email: ahnora@iium.edu.my.

*** Professor, Department of Legal Practice, Ahmad Ibrahim Kulliyyah of Laws, International Islamic University of Malaysia. Email: najibah@iium.edu.my.

**** Associate Professor, Department of Islamic Law, Ahmad Ibrahim Kulliyyah of Laws, International Islamic University of Malaysia. Email: roslinac@iium.edu.my. 
conversion to Islam. Thereafter, this article suggests that the government could provide assistance by empowering court bailiffs or enforcement bodies, increasing funding and to designate a special department for enforcement of divorce orders.

Keywords: native courts, enforcement of divorce orders, post-divorce orders, enforcement body.

\title{
CABARAN DALAM PENGUATKUASAAN PERINTAH SELEPAS PERCERAIAN DI MAHKAMAH ADAT DI MALAYSIA TIMUR
}

\begin{abstract}
ABSTRAK
Mahkamah adat di Malaysia terdiri daripada Mahkamah Anak Negeri Sabah dan Mahkamah Bumiputera Sarawak. Kewujudan mereka diiktiraf oleh Kerajaan Malaysia dan penubuhan mahkamah-mahkamah disebut dalam Perlembagaan Persekutuan. Walaupun mahkamah adat diberi kuasa untuk menangani undang-undang peribadi penduduk bumiputera di kedua-dua negeri, terdapat cabaran dalam penguatkuasaan perintah yang dikeluarkan oleh mahkamah tersebut dalam kes-kes pasca perceraian. Makalah ini penting memandangkan masih belum ada kajian dijalankan berkenaan tajuk ini. Objektif makalah ini adalah untuk mengkaji penguatkuasaan perintah perceraian yang dikeluarkan oleh mahkamah adat di Malaysia Timur pasca perceraian, mengkaji masalah dan cabaran yang dihadapi oleh mereka yang bercerai dalam menguatkuasakan perintah perceraian tersebut dan membuat cadangan untuk mengatasi masalah yang dihadapi. Seterusnya ini membolehkan usaha kearah memperbaiki sistem semasa mahkamah. Makalah ini menggunakan kaedah penyelidikan perpustakaan dan turut menggunakan kaedah kualitatif dimana ianya melibatkan perbincangan kumpulan dan temuduga bersama ketua kampung, ketua komuniti, hakim mahkamah bumiputera, hakim mahkamah rayuan bumiputera, pendaftar mahkamah bumiputera dan mereka yang bercerai. Hasil kajian menunjukkan terdapat empat cabaran yang perlu ditangani. Pertama, suami tidak dapat dijumpai setelah perintah perceraian dikeluarkan oleh mahkamah; kedua, suami gagal membayar nafkah; ketiga, kekurangan tenaga kerja dalam menguatkuasakan perintah, dan terakhir; suami menukar agama kepada Islam. Selepas itu, makalah ini mencadangkan kerajaan negeri untuk membantu mahkamah dengan menyediakan bailif atau badan penguatkuasa, meningkatkan pembiayaan dan mewujudkan satu jabatan atau badan dalam membantu mereka yang bercerai untuk menguatkuasakan perintah perceraian.
\end{abstract}


Kata Kunci: mahkamah adat, penguatkuasaan perintah perceraian, badan penguatkuasaan, penguatkuasaan selepas perceraian.

\section{INTRODUCTION}

Native courts in East Malaysia have been institutionalised and placed under each State prior to the formation of the Federation of Malaysia. These courts are not part of the Malaysian judiciary. The courts continued upon the formation of the Federation until today with their existence recognised under the Federal Constitution of Malaysia.

In discussing the enforcement of post-divorce orders, it is important to discuss the jurisdiction of Native Courts in East Malaysia. The Native Courts Ordinance of Sarawak was passed by the State Legislation of Sarawak on $17^{\text {th }}$ November 1992 ("the Ordinance") and was gazetted on $10^{\text {th }}$ December 1992 to preserve the practice of native court. Section 1(2) of the Ordinance ${ }^{1}$ provides that it is not applicable to a native professing the religion of Islam, except in cases involving Malay customs, native land, and special jurisdiction of a Resident's Native Court. ${ }^{2}$ The Native Court in Sarawak is known as Mahkamah Bumiputera (Indigenous Court), however, in this article it will be referred to as Native Court.

The Ordinance prescribed the jurisdiction of the Native Court which is mainly to hear cases inter alia, involving the laws and customs of the native which all parties are subjected to the native system of personal law and cases relating to any religious, matrimonial or sexual matter where one party is a native. ${ }^{3}$ The Native Court in Sarawak is a six-tier system ${ }^{4}$ where the lowest court is the Headman's Court presided by a headman with the assistance of two assessors; followed by Chief's Court at the second level and is presided by a Penghulu and assisted by two assessors. This is subsequently followed by the Chief's Superior Court presided by Temenggong or Pemanca assisted by two assessors or both Temenggong and Pemanca with an assessor. Then, the District Native Court is presided by a Magistrate with the assistance

\footnotetext{
Native Courts Ordinance 1992 (En. No. 3 of 1992).

Ibid, Section 20(1).

Ibid, Section 5.

Ibid, Section 13.
} 
of two assessors. Next, the second highest court, the Resident's Native Court presided by a Resident with two or more assessors and lastly, the highest court, Native Court of Appeal which is presided by a President with two or four assessors.

In Sabah, the Native Court Enactment 1992 provides that native court has the jurisdiction to hear cases relating to native customs. ${ }^{5}$ Further, the court must decide according to the personal laws of the parties in conflict. ${ }^{6}$ For instance, if the disputing parties are Kadazan, the court must decide by referring to Kadazan customary laws. The court has no jurisdiction in cases involving Syariah Court matters and cases under the jurisdiction of Civil Court. ${ }^{7}$

The structure of native court in Sabah is a three-tier structure. ${ }^{8}$ At the lower level is the Native Court that is presided by Ketua Anak Negeri (KAN) (Head of native) assisted by two Ketua Kampung (village headman). ${ }^{9}$ It is followed by the intermediate court that is the District Native Court which is presided by the District Officer with the assistance of two KANs. ${ }^{10}$ Whilst at the highest level is the Native Court of Appeal which is presided by a judge as the president and two District Officers or KAN as the assistants. ${ }^{11}$ The Native Court is under the Native Affairs Office which is administered by the Local Government and Housing Ministry. ${ }^{12}$ Native court of Sabah is known as Mahkamah Anak Negeri.

By virtue of Article 95b(1)(a) of the Federal Constitution of Malaysia, the native courts are under the jurisdiction of states. ${ }^{13}$ It is stated that the native law and custom includes the personal law of the natives with respect to any matter relating to marriage, divorce,

\footnotetext{
$5 \quad$ Native Court Enactment 1992 (En. No. 3 of 1992), Section 6(1)(a).

6 Ibid, Section 3.

7 Ibid, Section 9.

8 Ibid.

9 Ibid, Section 3(2).

10 Ibid, Section 4(2).

11 Ibid, Section 5(2).

12 Nancy Lai, "Upko Fully Backs Proposed Native Judicial Dept," Borneo Post Online, July 12, 2010,

http://www.theborneopost.com/2010/07/12/upko-fully-backs-proposednative-judicial-dept/ (accessed March, 27, 2013).

13 List IIa - Supplement to State List for States of Sabah and Sarawak, Federal Constitution of Malaysia, 1957.
} 
guardianship, maintenance, adoption, legitimacy, family law, gifts or succession, testate or intestate as well as the constitution, organization, and procedure of native courts (including the right of audience in such courts), and the jurisdiction and powers of such courts. In this article, whenever a "case" is mentioned, it refers to matrimonial cases only.

The hierarchy and court structure of each State begins with the court with the most power. At the bottom of the pyramid of the native court structure is the village headman court or Ketua Kampung. The Ketua Kampung has the right and power to solemnise a marriage and grant a divorce to the native couple. In most cases, the couples would agree to all the terms. If any of them is not happy, he/she would go to the second level of court, either Mahkamah Anak Negeri or Penghulu Court. In the second level, the Ketua Kampung has no power/jurisdiction and would not interfere anymore, and the court will deal with the matter. Ketua Kampung is given the power to deal with all matters relating to adat (custom) and decide according to the undang-undang adat (customary law).

In divorce matters, the Ketua Kampung will listen to both parties and their allegation and thereafter decide the matter according to the customary law. In issuing divorce, the Ketua Kampung will impose adat on the couple who has committed wrong which lead to the divorce. He/she must later pay penalty or sogit. If the parties have agreed to an agreement prior to the date of the hearing, the Ketua Kampung will let them adhere to the agreement and impose penalty (if any). The Ketua Kampung did not issue an order in paper form but in oral. After the divorce, the Ketua Kampung will send a report to the Penghulu (headman) for him to place his signature and officially approve the divorce. A letter will be issued by the Ketua Kampung as to enable the couple to register their divorce and cancel their marital status at the National Registration Department.

In a scenario where any party does not honour the term of the divorce order, the other party may again meet the Ketua Kampung and lodge a complaint about it. The Ketua Kampung will call both parties for a meeting and investigate the reason for the default. The defaulting party will be given a chance to comply with the divorce order. If the default party failed to attend the meeting for few times or failed to comply with the terms after being given a chance to do so, the case will be brought to court next in hierarchy. 
In a scenario where the couple is not satisfied with the decision of the Ketua Kampung, they may bring their case to the Penghulu or Ketua Anak Negeri. At the next level of the court, the formal way of proceeding begins. The couple or any unsatisfied party needs to register their case and take a mention or hearing date and thereafter follow the procedure of the native court.

In this article, the discussion is limited to the post-divorce order issued by the native court and the challenges faced by the divorcees in enforcing the same. It is worth highlighting that there are a few stages in the divorce matter; first, the disputing couple decides to divorce either with mutual consent or contested; second, they go through all the procedures to obtain the divorce order from the native court or Ketua Kampung and lastly, they have to put effort in enforcing the divorce order issued by the court. This article studies the current challenges faced by the divorcees in enforcing the divorce order issued by the native courts and provides recommendations on how to overcome them.

\section{PROBLEM STATEMENT}

The natives in East Malaysia depend on the native court for the resolution of issues and problems. The native courts that apply customary laws are given the power by the States to grant and enforce divorce orders. However, there are challenges in enforcing such orders. The divorcees found that it is difficult for them to enforce the order. Hence, this article provides recommendations to the States in overcoming such challenges.

\section{OBJECTIVE OF THE RESEARCH}

This article seeks to achieve the following objectives: -

1. To study the enforcement of post-divorce order in native courts in East Malaysia.

2. To examine the problems or challenges faced by the divorcee in enforcing the divorce order. 
3. To recommend solutions on how the problems faced by the divorcee could be addressed when enforcing the divorce order.

\section{RESEARCH METHODOLOGY}

This article applies both qualitative and library-based research methods. The latter is used in searching for information and data from material such as legislation and secondary sources of materials such as textbook. 80 respondents from both States are involved in applying the qualitative research. Data was collected through interviews and focus group discussions. The interview sessions were divided into two parts: a mini-interview and one-to-one in-depth interview. The interview was adopted as one of the research methods in order to extract some information through short open-ended questions. The aim of these interviews were to assess the experiences of these respondents on enforcing the post-divorce order. The questions focus on; enforcement procedures for the order; second, challenges faced in enforcing the order and third, whether there is any government or private agency or non-governmental organisation assisting to enforce. Meanwhile, the one-to-one in-depth interview was designed with unstructured and open-ended questions. These were used to explore the steps to be taken in overcoming the challenges.

In a qualitative research, in order to produce effective findings, the researcher must determine whom to interview and how many participants or data resources are necessary. ${ }^{14}$ Therefore, the right persons must be chosen to participate as the sample since "sampling is about choosing the right participant". ${ }^{15}$ In conducting research for this article, the samples are chosen from village headman (ketua kampung), headman (penghulu), community leaders (ketua masyarakat), native courts' judges, native court of appeal's judge and registrar of native court. Focus group discussions with the divorcees, village headman, headman, community leader, and judges of native courts were conducted in each State to gather information on the enforcement of

14 Lisa Webley, "Qualitative Approaches to Empirical Legal Research" in The Oxford Handbook of Empirical Legal Research, ed. Peter Cane and Herbert Kritzer (Oxford University Press, 2010), 933.

15 Alexander C. Wagenaar and Scott C. Burris, Public Health Law Research: Theory and Methods, (John Wiley \& Sons, 2013) 340. 
the post-divorce order. The samples and methods adopted in this article are sufficient to furnish findings that could lead to the next action that needs to be taken in the research.

\section{LIMITATIONS}

In this article, the research is limited to certain areas in Sabah and Sarawak only and The Federal Territory of Labuan is excluded due to time constraint. The areas involved are Kota Kinabalu, Membakut, Kota Marudu and Kota Belud, Sabah and Kuching, Kota Samarahan, Samarahan, Miri and Limbang/Lawas, Sarawak. The data collection started in November 2017 and completed in January 2018. The divorcees in this research are also single mothers.

\section{FINDINGS}

The findings of this article are divided into three parts, findings from the mini-interviews, one-on-one interviews, and focus group discussions.

\section{Findings from the mini-interviews}

Findings from mini-interviews showed among others that; ninety per cent of the respondent interviewed complained that it was difficult for them to enforce the divorce order granted by the native court. Second, ten per cent of the respondents have no problem in enforcing the order because they have nothing to claim from the husband, including the maintenance for children or the husband does not have any obligation towards them. Basically, for the second group, the divorce order was needed to separate them formally. On the other hand, the earlier group found that it is difficult to enforce the order due to the reasons grouped into the following:

a. the other party could not be found or contacted upon receipt of the divorce order.

b. the other party failed to honour the court order despite the fact that he has been given few chances to perform his obligation. 
c. husband has no permanent job and unable to pay maintenance as ordered by the court.

d. husband has remarried and unable to provide maintenance as ordered by court; and

e. the other party does not cooperate in dividing matrimonial property.

\section{Findings from focus group discussion (FGD)}

The respondents involved in the focus group discussions are comprise of the divorcees, village headman, headman, community leader, and judges of native courts. In the four sessions conducted, the respondents agreed that there are some challenges faced by the divorcee in enforcing the order. The findings of the discussions are provided below.

\section{The Challenges faced by the divorcees are:}

i. $\quad$ some husbands tried to escape the responsibility of paying maintenance.

ii. most of the times, upon divorce the party will move to other places and unable to be contacted.

iii. the defaulting party either cannot be contacted or refused to come to court; and

iv. the court is unable to assist in enforcing the divorce order.

The effects of inability to enforce the order from the divorcees' point of view:

i. The divorcees feel that there is no way out but to bear with the situation.

ii. the divorcees feel hopeless and neglected by the justice system; and

iii. the divorcees feel that there is no need to go to court if the husband defaults because there will be no action taken or the 
action taken by the courts is fruitless from the experiences of their family or friends who are also divorcees.

\section{The Challenges faced by the native courts are listed below:}

i. no proper enforcement body;

ii. court staff unable to contact the divorcee if they change their contact number and move to another place. If the divorcee moved from a house to another or to a rural area which the native customary law is applicable, still the court put effort and manages to contact them. However, if the divorcee moves to another city or overseas, the court will not be able to contact the subject;

ii. the native court judge issued letter calling the divorcee to attend a hearing and he/she refused. Subsequently, a second or third letter is issued but still the divorcee failed to attend court. In certain areas, the court gets assistance from the police to summon him/her. But not all the courts do this. So, there is no ending to this issue;

iii. if the divorcee attends the hearing, the presiding officer or native judge will issue an order of contempt of court. But later no further action is taken.

\section{Findings from the one-on-one in-depth interview}

The findings from one-on-one in-depth interviews showed that there are few reasons for the inability to enforce the divorce order. The interviewees shared their experiences in handling this issue and suggest solutions to solve this problem. The reasons and suggestions are grouped into few points as mentioned below.

\section{The reasons for the inability to enforce the divorce orders}

i) The husband could not be found

One of the reasons that are agreed by most of the interviewees was that the husbands were missing and could not be contacted. They do not even contact the ex-wife to meet the children. In most of the cases, the 
divorcee will migrate or move to other district after divorce. Some of them migrated to work overseas and come back after few years.

$\mathrm{AW}^{16}$ is a headman, native court judge and one of the community leaders who has been involved with the community for twenty years. He said from his experience, many husbands do not pay maintenance and gone missing. ${ }^{17}$

There are many (husbands) who do not pay maintenance. Sometimes, they are forever missing (hilang terus), could not be found at all. The court cannot enforce (the divorce order) because the husband could not be found. ${ }^{18} \mathrm{MZ}$, a village headman agreed with AW and said that he does not know what to do when the husband is missing.

If the husband could not be found, I do not know what else to do. ${ }^{19}$

This is also agreed by $\mathrm{TH}$, a registrar at the native court who has been involved with the native laws for thirty years and has once been appointed as a district officer. He says,

The other thing is some of this husband, after they divorce, they no longer stay in that locality. How can we trace. No one trace. Today they may be in Kuching, tomorrow in Singapore in Jeddah or Saudi Arabia or somewhere in New Guinea, where the timber camp is. And they may come back five years later. ${ }^{20}$

ii) Husbands' default in payment of maintenance

One of the reasons that caused the divorce order to be unenforceable is because the husband defaulted with unknown reason either to the wife or the court. In certain cases, it is difficult for the court to enforce the order because the husband simply does not want to make payment for

16 In order to protect the privacy of the respondents, the names of the respondents who were interviewed will not be divulged. Instead, they will be referred to based on their initials only.

17 Interview session with respondent on December 3, 2017.

18 Ibid.

19 Ibid.

20 Ibid. 
maintenance. It is difficult to find a case where payment is made continuously. This point is shared by RE, a headman and community leader who is also a native court judge or proceeding officer. He says,

When it comes to the native laws that involve maintenance, in fifty cases, may be one will pay maintenance for two or three months and after that no more. It is infrequent to find cases where maintenance is paid continuously. ${ }^{21}$

SB who is a young village headman, support RE's statement. He says that the refusal of many husbands to pay maintenance caused the wives to complaint to him. He says,

The wives keep coming to complain to me about their husband failure in paying maintenance. I called the husband many times and he promised to pay but again he defaults. As a village headman, I do not have any power to enforce the judgment but sent the cases to the native court. ${ }^{22}$

It is agreed by $\mathrm{TH}$ since he has been listening to complaints from the headmen that many husbands defaulted in paying maintenance. He says,

We have feedbacks from the Penghulu from the people there, the women, the divorcee. First month they (husbands) pay in full. The second and third month zero. ${ }^{23}$

One of the reasons for divorce is the financial problem faced by the couple. From the interviews, it is found that a wife does not want to stay together with a husband who is unable to provide for the family which caused her to get a job and bear all the household expenses. According to $\mathrm{CH}$, a community leader and a tuai rumah (the head of a long house), a wife responsibility is not similar as a husband who supposed to feed the family. She explains,

Most of the wives are having problems relating to maintenance.

In a particular case, the husband was asking for maintenance

${ }^{21}$ Interview session with respondent on December 23, 2017

${ }^{22}$ Interview session with respondent on December 22, 2017.

${ }^{23}$ Interview session with respondent on December 3, 2017. 
from the wife. How come the wife has to bear all the responsibility. The responsibilities of wife and husband is different. How come the wife has to take the husband's responsibility just because she is working. ${ }^{24}$

In many cases, the husband is unable to pay maintenance because his earning is either insufficient or he did not earn at all. Hence, the husband's financial constraint caused the inability to enforce the divorce order. AW in supporting this point says,

Sometimes, the husband is unable to pay. Even though the court has issued order on maintenance, he still did not pay because he has no money to pay. ${ }^{25}$

\section{iii) Lack of Manpower}

The native courts are given power to enforce any order or judgment. However, they lack manpower in enforcing the order. RE explains that the States conferred power to the native courts in enforcing its order in all matters not only for divorce. However, the native courts are not given sufficient manpower to execute it. He says,

The native court has the power conferred by the Native Court Ordinance to send anyone who commits contempt of court to jail. However, the headman or village headman is unable to do everything by themselves. There is no one in native court assigned to do this part in enforcing the court order. ${ }^{26}$

DE, a community leader, and a headman further state,

The native court can only grant a judgment/order but there is no body / personnel to enforce the judgment/order. For example, in contempt of court cases, the court has power to issue order of contempt, but it cannot be enforced. ${ }^{27}$

\footnotetext{
${ }^{24}$ Interview session with respondent on December 4, 2017.

${ }^{25}$ Interview session with respondent on December 3, 2017.

${ }^{26}$ Interview session with respondent on December 23, 2017.

${ }^{27}$ Interview session with respondent on December 2, 2017.
} 
AW shares his experience in a case where a husband does not honour the court's order. But there is no action taken by the court because it lacks manpower in enforcing its order. He explains,

When a wife in an area made a complaint that her husband did not honour the court order, summon will be issued to him calling him to come to court and explain the reason for defaulting the court order. But again, he ignored and did not come to court. The court may issue order for contempt of court, but no one will enforce the order. ${ }^{28}$

$\mathrm{BM}$ who is a district officer and native court judge further explains this situation. The court is depending on the police department to assist in arresting the defendant after warrant of arrest is issued. If the police are unable to assist, the court cannot do anything. He says,

After the judgment there is no enforcement. Even if we issue a warrant of arrest, still we are at the mercy of the police. If they don't act on it, then nothing happens because we have no control of the police personnel. Even staff, especially admin staff are not available, we only depend on the district officer. There is lack of staff and the court might not be able to ensure that the person is brought to court. ${ }^{29}$

HT agreed with the earlier explanation and clarifies that police is needed since the court is not provided with bailiff. He says,

As far as enforcement is concerned, there is no bailiff. The law is there. But there is no bailiff. ${ }^{30}$

MZ's opinion supported HT's view. In fact, in MZ explanation he further clarifies that the enforcement in native court and civil court is no similar since native court has no bailiff. However, if arrest is needed, the court will call the police for an assistance. He says,

The enforcement in civil court includes bailiff. However, in native court that part is missing. We do not have bailiff. In native court we only follow native customary law. The native court has

\footnotetext{
${ }^{28}$ Interview session with respondent on December 3, 2017.

${ }^{29}$ Interview session with respondent on December 24, 2017.

${ }^{30}$ Interview session with respondent on January 21, 2018.
} 
the power of arrest but with the help from the police. If the case is a serious one and police is needed, the court will call the police. However, in my area, there is no such case as yet. ${ }^{31}$

DTAJ, the President of the Appeal Native Court, explains that the law granted the native court power to enforce its order or judgment. However, the court is lacking the manpower and the specific personnel such as bailiff. He explains that the law mention sheriff not bailiff. But the function of the two is the same, so, both terms are used interchangeably. He states as follows:

That part of enforcement of judgment or order, we have problem. Even now we have a problem. In adat code, no provision for enforcement of judgment. But in our native court, the divorce is done by the Penghulu. The lowest is the headman court. Chief court is the penghulu court. Divorce and marriage are done by headman. First, the marriage is done by headman. Then he will tell the Penghulu that he has done the marriage with all the celebration. The Penghulu will sign the marriage certificate. When there is divorce, they go to the Chief Court/ Penghulu court. They can give the divorce under the adat.

After judgement is entered, he did not pay. After one or two months did not pay. We register under Form F1 to show cause why you did not pay according to court order. When he comes, the Penghulu will take pro-active part to examine him, why he did not pay. Like judgment debtor in civil court. It is the same procedure. If he got something like property, we could sell. So, we examine him. We give him time to pay a lump-sum payment or instalment.

Rule 11 of the native court provides for enforcement of judgment order. After you enter judgment in Form $\mathrm{F}$ or $\mathrm{S}$, if the party failed to honour the judgment, the court could call them and issue a show cause letter the reason he/she failed to do so. This show because letter need to be served on the party just like civil court. The court will ask the party why he failed to pay (the maintenance). If he got the means to pay, the Penghulu will give him time. He still failed and he has a property, the law is clear that you (the court) can seize the property. The action will be taken by a sheriff or bailiff. But here, we have no bailiff. The

31 Interview session with respondent on December 3, 2017. 
law requires bailiff, but we do not have. We cannot sell the property because we have no body to carry out the order. Law requires bailiff but we have not appointed bailiff to carry out the order. We have requested but the government has not given us, so far, we are waiting for them to give us bailiff. The law of our native court talks about sheriff. The rule is here... but we do not have bailiff. ${ }^{32}$

iv) The Husband converted to Islam.

Native law is very clear that it is not applicable to natives who profess the religion of Islam in the matter that fall under syariah laws. ${ }^{33}$ One of the reasons the divorce order is not enforceable is because the husband has converted to Islam. Hence, the native customary laws are not applicable or enforceable on him. The cases are not many but do exist. The husband migrated or moved to find a job. Later he converted to Islam and remarried a Muslim woman. HT says,

Husband comes back and straight to the Mahkamah Syariah (Syariah Court). What would happen to the non-Muslim wife and the children? $?^{34}$

\section{DISCUSSIONS AND RECOMMENDATIONS}

The challenges faced by the divorcees in enforcing court orders are due to five factors; first, the husband is not willing to take responsibility or to evade his obligation in paying maintenance which caused them to move away and could not be contacted; second, the husband is willing to honour the divorce order but unable to do so because of financial constraint on his part; third, the husband is missing; fourth husband convert to Islam and lastly, the court is unable to take action due to lack of staff and financial issue.

From the focus group discussions, the divorcees sought government assistance in enforcing the court order; provide financial assistance so as to enable their children to have a proper education despite of any financial issue and assist them to establish their own

32 Interview session with the respondent on January 21, 2017

33 Section 9, Native Court Enactment 1992 (En. No. 3 of 1992).

34 Interview session with respondenton January 21, 2017 
business, so they would be independent financially in future. The court officers also made some suggestions to resolve the issues. They suggested that the court is to be provided with more staff because the court needs enforcement personnel such as sheriff or bailiff. This is important because currently the court may issue a contempt order, but no one will enforce it due to lack of staff. Hence, the state government is called to assist the court to form the enforcement body. Secondly, there is a need for a body in assisting the divorcees to enforce the divorce order especially matters relating to maintenance of children. Lastly, the State needs to link the native court and other authorities such as police and immigration department in a formal way. Thus, it is possible for the court to find the missing husband and thereafter take action with the assistance of sheriff.

There are also some suggestions made by the respondents from one-on-one in-depth interview in this research. First, it is suggested that the Native Court to have more collaboration with the police. The interviewees suggested that the court institution to have formal memorandum of understanding with the police department. Therefore, the native court will have complete assistance from the police department. SB says,

The court needs to have collaboration with the police. ${ }^{35}$

The system is inadequate without an enforcement body. It cannot be expected from us (village headman, headman, community leader and native court judge) to do everything including enforcement such as arresting the party. ${ }^{36}$

Second, the State needs to assist the native court in getting adequate manpower. Lack of manpower has become an obstacle for the court to provide service efficiently to the native people. Further, it stops the court in carrying out the enforcement properly. Therefore, more allocation in terms of money should be allocated to the native courts as to enable them to have sufficient manpower. The native court later may form its enforcement body by having bailiff and/or other methods. This step is crucial to avoid the repetition of the same problem in future.

\footnotetext{
35 Interview session with respondent on December 22, 2017.

36 Interview session with respondent on December 24, 2017.
} 
It is necessary for us to have an enforcement body to ensure all orders are enforced. Otherwise, the defaulters will migrate and become missing. This enforcement body will cater for this issue. We cannot let them (the husband) to be irresponsible. To divorce their wives and leave their child proved that are irresponsible people. $(\mathrm{AB}$, community leader). ${ }^{37}$

It is important to have an enforcement body, so the husband cannot evade his responsibilities after divorce. The effect of non-performance in enforcement, the plaintiff blames the native court. For me, we need an enforcement body not only to enforce the order for maintenance, but to all offences committed by the defendants. Sometimes, we as the presiding officers feels there is a need to charge some defendant for contempt of court. But, knowing that there is no one to enforce it, we do not do so. There is law on contempt of court but there is no enforcement. As a headman, I can issue letter of arrest but who will carry out the action as there is no bailiff. We have the law but no enforcement body. There is a need for one. (RE) ${ }^{38}$

If we can have an enforcement body that is given powers to deal with the authorities such as police and immigration department, the said body will be able to help the party to enforce her judgment/order. (DP, a headman and native judge). ${ }^{39}$

It is important to have an enforcement body to enforce the court judgment/order. At the same time, it will assist the party since no one is assisting the party. (FAT, a headman and community leader). ${ }^{40}$

Thus, from the suggestions made by both groups, it is recommended for the government to assist the divorcees in enforcing the divorce order, provide financial assistance, established enforcement body such as bailiff or sheriff, provide sufficient manpower, link the native court with other authorities in ensuring the smoothness of the court order enforcement such as in finding missing person.

\section{CONCLUSION}

There must be a step taken by the authority in overcoming the challenges faced by the divorcees. Therefore, this article would like to

37 Interview session with respondent on December 27, 2017.

38 Interview session with respondent on December 23, 2017.

39 Interview session with respondent on December 25, 2017.

40 Interview session with respondent on December 2, 2017. 
adopt all suggestions made by the divorcees herein. The State government and the native court must work together in overcoming this challenge.

In addition, it is suggested for the State government to work together with the Federal government in establishing a family support agency by following the program provided by the Syariah court i.e., Badan Sokongan Keluarga (BSK) (Family Support Agency). The function of this agency is to assist the divorcees in enforcing maintenance order to prevent the husband from neglecting the child welfare.

Further, it is recommended for the State government to increase the financial assistance to the native courts. The money will assist them to bear the charge imposed for each person sent to prison for contempt of court since civil matters are not covered by the Department of Prison. The native court is seen as ineffective because the native people are unable to see the action taken by them. On their part, they are unable to take any action since they are facing some obstacles due to lack of manpower and financial constraints. It is also recommended for the native court to work together with the state's religious department in assuring the husband has resolved all issues relating to his marriage before his conversion to Islam. These challenges can be resolved if all parties work together.

It is hoped that the suggestions and recommendations herein mentioned will be materialised and actions will be taken as to have a better future for the native divorcees and the children in both East Malaysia. 